\title{
International Cooperation in Adaptation to Climate Change: Foreign Agendas or Local Necessities?
}

\author{
Paulina Virues-Contreras ${ }^{1}$, Laura Ruelas Monjardin², Beatriz Del Valle-Cárdenas ${ }^{1}$ \\ ${ }^{1}$ Regional Sustainable Development Academy, The Veracruz College, Veracruz, Mexico \\ ${ }^{2}$ Postgraduate and Research Department, Xalapa Higher Technological Institute, Veracruz, Mexico \\ Email: paulivirues@gmail.com, laura.rm@xalapa.tecnm.mx, beatriz.delvalle@colver.info
}

How to cite this paper: Virues-Contreras, P., Monjardin, L. R., \& Valle-Cárdenas, B. D. (2020). International Cooperation in Adaptation to Climate Change: Foreign Agendas or Local Necessities? American Journal of Climate Change, 9, 480-505. https://doi.org/10.4236/ajcc.2020.94030

Received: September 29, 2020

Accepted: December 27, 2020

Published: December 30, 2020

Copyright $\odot 2020$ by author(s) and Scientific Research Publishing Inc. This work is licensed under the Creative Commons Attribution International License (CC BY 4.0).

http://creativecommons.org/licenses/by/4.0/

\begin{abstract}
The paper aims to analyze climate change adaptation projects funded from international cooperation in Veracruz, which is a Mexican state. They used 5 criteria based on international, national and local dimensions as well as their relation to climate adaptation. From this evaluation, they were able to determine that the results were particularly negative. Mostly, because the objectives set by donor countries are scarcely related to the objectives and priorities of recipient countries, in this case developing countries, which are the most vulnerable to climate change. This provides insight into international collaborative projects in developing states and their impact on the socioeconomic, environmental and vulnerable ecosystems.
\end{abstract}

\section{Keywords}

Adaptation to Climate Change, Adaptive Capacities, International Cooperation, Vulnerability to Climate Change

\section{Introduction}

International cooperation for climate change policies has been mostly to amend the ecological debt historically contracted by industrialized countries to developing countries. Industrialized countries account for the highest amount of greenhouse gas (GHG) emissions and bear more responsibility for global warming (Eckstein, Künzel, \& Schäfer, 2017). It is argued that one component of the ecological debt is the unpaid disposal cost of gas residues, such as carbon dioxide $\left(\mathrm{CO}_{2}\right)$, which greatly contributes to global warming. The proposed payments for the disposal or emission of GHGs, while currently not met, are based on the 
concept of carbon sinks or reservoirs, to sequester carbon. One purpose of international cooperation agencies in this context may be to correct the actual monetary costs of environmental services, resource use, or degradation. Although ecological debt is based on ecological themes has spread to social, cultural, and economic issues (Goeminne \& Paredis, 2008; Warlenius, 2016), as well as a tool for reframing and reorienting national and international sustainable development policies (Paredis et al., 2008).

International cooperation was defined by Marcellesi (2012) to include the set of actions and tools of international nature aimed at the transfer of economic and human resources to developing countries that are among the most vulnerable to climate change. From 1997 to 2016, nine out of the ten countries most affected by climate change were developing, low-income countries (Eckstein, Künzel, \& Schäfer, 2017). However, international cooperation to promote development should not be understood as a static process, but rather as a dynamic process that must be adjusted to the particular necessities of territories and specific historical contexts. At the same time, it is important to bolster governance capacity in order to ensure a unified vision of collaboration, participation, and action between social actors and the state itself (Requena, 2014), which, without a doubt, represents a challenge.

Climate finance is a highly political and hotly contested issue during climate change negotiations because of its complexities. The United Nations Framework Convention on Climate Change (UNFCCC) recognizes the need for new and additional finance mechanisms to help developing countries prepare for climate change as appropriate, urging agreement and cooperation among all parties. However, in learning lessons from past experiences with development finance, they stress that climate finance needs to be more effectively delivered and secure the highest possible amount of development benefits while also addressing the fundamental needs required to tackle climate change. Nonetheless, the top-down, highly bureaucratic and specialized approach of international agencies, in addition to lack of participation, accountability mechanisms, and evaluation are factors considered to have diminished the impact of international cooperation (Bronfman \& Díaz Polanco, 2003). After growing by some 60 percent over the previous decade, global aid peaked in 2010 and now looks set to decline or at best stagnate, as most donor countries pursue fiscal consolidation and public debt reduction strategies and as more countries graduate from low-income status (Evans and Davies, 2015). Thus, the relationship between the actual needs of recipient countries and the allocation of funds by donating agencies needs to be further investigated, especially considering that adaptive climate-change measures require considerable resources for their implementation. Poor countries will only engage in mitigation measures, given the high cost for adaptation (Buob and Gunter, 2011). A research conducted by Debela et al. (2019) in South Ethiopia, with pastoral and agropastoral households, found out that the three key barriers that conditioned their adaptive capacity were limited finance, expertise and access to weather/climate information. By 2015, The United Nations Devel- 
opment Programme (UNDP) had estimated that the amount needed to implement adaptive measures could spiral to US $\$ 86$ billion annually. The longer it takes to implement an effective international agreement to reduce GHG emissions, the higher these costs of adaptation will be and the more likely it will be that the capacity to adapt will be either reached or exceeded.

Existing international funding to support climate change adaptation in low and middle-income countries, like Mexico, comes from two main sources: dedicated climate change funds of the UNFCCC and the Official Development Assistance (ODA). Currently, both of these avenues fall significantly short of meeting the actual costs of adaptation in low- and middle-income countries. Thus, the scarce funds must be focused on the actual necessities of local populations, taking into consideration their vulnerability in regard to the geographical, natural, economic, and political context. However, measuring vulnerability is difficult because it requires the consideration of both qualitative and quantitative data and the dynamic character of the biophysical and social processes of a region (Stern et al., 1992; Neil, 2006; Ashan \& Warner, 2014). Also, there is a lack of universal guidelines or indicators for the evaluation of vulnerability (Mussetta et al., 2017). In the face of these difficulties, one of the strategies to reduce vulnerability is through evaluating the ability of social groups or collectives in a determined location to cope with and adapt to external stressors placed on their livelihoods and well-being.

In this context, the adaptive capacity is understood as the capacity of a system to adjust its characteristics or behavior or to expand its range of tolerance to existing or future climate variability. Thus, a system with a high adaptive capacity is able to create or implement effective adaptation strategies or to adequately react to current threats or pressures so as to reduce the probability and/or the magnitude of harmful impacts stemming from climate change (PNUD, 2010). Different research studies have analyzed the adaptive capacity of communities, regions, and nation states in terms of their vulnerability to changing environmental and social conditions or in terms of the factors that may enable or prevent them from adjusting to changing conditions (Adger \& Kelly, 1999; O’Brien et al., 2004).

The monitoring and evaluation of adaptation to climate change have become increasingly relevant in recent years at the international and national level, including the identification of adaptation actions and the actors who have implemented them as well as the sectors that have benefitted and whether resources have been used efficiently (Zorrilla \& Altamirano, 2015). One example is the indicators for adaption generated by the World Bank for use in the United Kingdom (Miller, Harley, \& Kent, 2012) as well as the indicators generated by Inter-American Development Bank (Miller et al., 2013). The German Agency for International Cooperation (GIZ) also developed in 2014 a set of indicators for use in Mexico.

However, the indicators should be adapted to the local context, for this reason, it is important to analyze projects financed by international cooperation 
agencies with the aim of promoting adaptive capacity at the local level. In this regard, the objective of the present study was to determine the contribution of projects financed by international cooperation agencies toward increasing the capacity of the natural and socioeconomic systems of the coastal state of Veracruz, Mexico, to adapt to the effects of climate change. For this, we used a series of indicators to evaluate the efficacy of these projects, in terms of the type of projects that received the most international support; the municipalities that were the most benefited and; the adaptation costs financed through international cooperation agencies.

The state of Veracruz was selected because it is one of the most vulnerable states in Mexico to the impacts of climate change (Tejeda, 2009). Interestingly, it is also the first entity in Mexico to enact a climate change law. The legal support for climate change policies positioned Veracruz as a focal point for the development of programs and projects to combat climate change and as a partner for international cooperation.

\section{Methodology}

\subsection{Study Case Description}

The geographical characteristics of the state of Veracruz, Mexico (Figure 1) exacerbate its physical and social vulnerability to climate change (Tejeda, 2009). Notably, $72.2 \%$ of its territory is located 0 to 200 meters above sea level (Ortiz et al., 2010). However, the state also has a varied topography and contains the highest mountain in Mexico at an elevation of 5747 meters above sea level. It is the Mexican state with the third highest biodiversity and it has more than 40 climate types (CONABIO, 2013). Thirty-five percent of Mexican river ways and water bodies are located in Veracruz, which has six unique hydrological regions and 14 hydrological basins (INEGI, 2016).

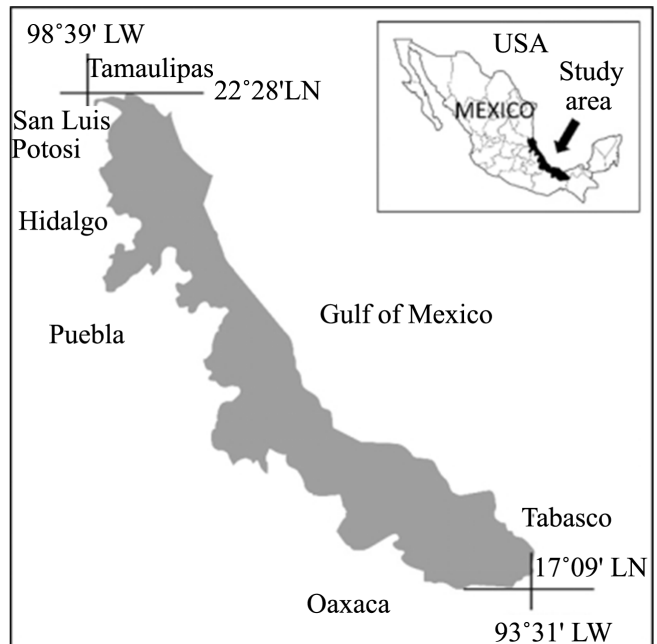

Figure 1. Geographic location of the state of Veracruz, Mexico, a coastal, populated and biodiverse state vulnerable to sea rise level-put more detail in this legend. Source: Martínez et al. (2007). 
The state contains a population of over eight million habitants (INEGI, 2015), occupying third place nationally. The majority of the population is urban (61\%), although the rural population is also significant (39\%). Politically, it is divided into 212 municipalities and 20,828 localities. However, it is among the four entities with the highest degree of social marginalization (CONEVAL, 2016), and $61.8 \%$ of its population lives in poverty (CONEVAL, 2018). The coasts-low, sandy, with large adjacent wetlands, less than a meter above sea level-represent the fraction of Veracruz territory most vulnerable to sea level rise, which will affect villages and ecosystems, as well as causing saltwater to infiltrate aquifers (Tejeda, 2009). These authors consider that the state will have a maximum range of likely ocean impact over six meters of altitude, starting at the current average sea level for the next hundred years, and a minimum of $60 \mathrm{~cm}$. Increased rate of warming and combined effects increase likelihood of overstepping the adjustment threshold value. Other negative consequences are the exacerbation of violence, emigration, and social inequality (Maldonado \& González, 2013).

\subsection{Methods}

The methodology was mixed, as both quantitative and qualitative data were considered from primary and secondary sources. The conceptual model of evaluation is illustrated in Figure 2 to highlight the primary sources and analysis of quantitative data. The methods were geared toward assessing the adaptive capacity along the following five dimensions: 1) vulnerability of municipalities to climate change, 2) alignment of projects with national climate change policies, 3 ) contribution to the adaptive capacities of the natural sector, 4) contribution to

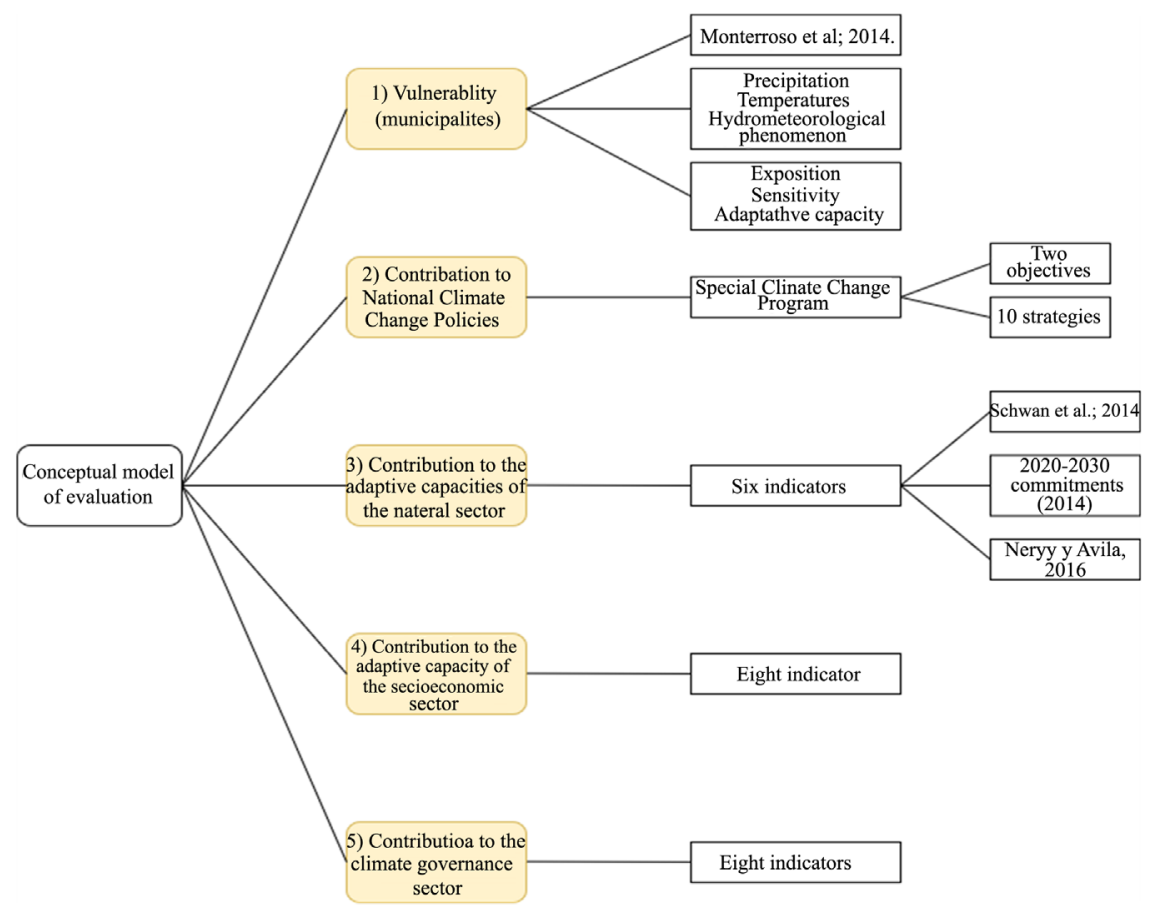

Figure 2. Conceptual model of evaluation. 
the adaptive capacities of the socioeconomic sector, and 5) contribution to climate governance.

First, the vulnerability of the municipalities of Veracruz was determined. For this, the vulnerability diagnosis of Monterroso et al. (2014) for Mexico was used given its applicability to the unique context of Mexico. Specifically, this diagnosis was based on an exhaustive review of historical data, previous studies, and future scenarios and also takes into account hydrometeorological data. The vulnerability score is calculated according to a formula considering the exposure (E) and sensitivity (S) to climate change and the adaptive capacity (AC). According to Monterroso et al. (2014) and Fritzsche et al. (2014), exposure is directly linked to weather parameters such as temperature and precipitation. Sensitivity is typically integrated by natural and/or physical attributes of systems, such as topography, type of coverage, etc. It can be said that these are human and environmental conditions that can worsen or lessen the impacts of climate change. Adaptive capacity is the ability to modify characteristics or behaviors to better cope or anticipate change factors. Some of the variables that define it are living conditions of people, aspects of organization, knowledge, economic situation, degree of wealth of ecosystems. That is why increasing adaptive capacities reduce the level of vulnerability.

$$
\mathrm{V}=\mathrm{f}(\mathrm{E}+\mathrm{S})-\mathrm{AC}
$$

In following, the Special Climate Change Program (PECC, 2014-2018) elaborated by the Intersecretarial Commission on Climate Change (CICC) of Mexico was revised to evaluate whether the projects financed by international cooperation agencies contributed to the fulfillment of the objectives, strategies, and lines of action outlined in the program. Notably, the CICC is composed by members from 15 of the 16 state secretariats, except for National Defense. It is a governance mechanism that coordinates with the Climate Change Council to promote society's participation and fulfillment of the applicable provisions of the Planning Law. The Climate Change Council is CICC's permanent advisory body and is composed of members from the social, private and academic sectors, with recognized merits and experience in climate change. Its functions include: 1) advising the CICC and recommending studies, policies and actions, as well as setting targets to address the adverse effects of climate change and;2) promoting social participation, informed and responsible, through public consultations.

To evaluate the adaptive capacity of the natural and socioeconomic sectors, Schwan's 50 international indicators (Schwan, 2014) were used. These consider the adaptation context in order to determine whether the adaptation or investment strategies meet their objectives. Specifically, at the national level, the strategies in the "Mitigation and Adaptation Commitments for Climate Change for the 2020-2030 Period" (Gobierno de la República Mexicana, 2014) were evaluated. In this case, the highlighted strategies and actions prioritize the protection of the population from the extreme effects of hydrometeorological phenomena and also strive to increase the resilience of the country's strategic infra- 
structure and ecosystems. At the local level (the state of Veracruz), Neri and Ávila's indicators (2016) were used: These authors proposed a methodology for measuring adaptation actions and advances carried out by the state government or at the municipal level.

The aforementioned information was used to formulate an open-ended questionnaire. The aim was to understand the perception of experts regarding climate adaptation projects and whether they contributed to increasing the adaptive capacity of natural and social systems in the state of Veracruz. The questionnaire was sent electronically to three type of actors: 19 international cooperation agencies, 9 federal and state government agencies related to environmental issues, and 12 key informants (researchers, public servants, and representatives of civil associations). These actors were identified in the registry of the Mexican Agency for International Development Cooperation (AMEXCID), publications of the Institute of Ecology and Climate Change (INECC), and the Secretary of the Environment of the State of Veracruz (SEDEMA). The considered international cooperation agencies were those that implemented or allocated resources for projects for the mitigation of or adaptation to climate change in the state of Veracruz in the 2010-2016 period. To evaluate the perception of the experts, a vertical or intratextual analysis was performed (Piñar, 2012), in which the responses that occurred most frequently (General response patterns) were selected and classified into mutually exclusive topics.

\subsection{Data Analysis}

In order to assess the dimension (1) "vulnerability to the CC of the Veracruz municipalities", a reference was made to the study done by Monterroso et al. (2014) (Figure 3).

The municipalities where the projects were carried out a score were assigned (Table 1).

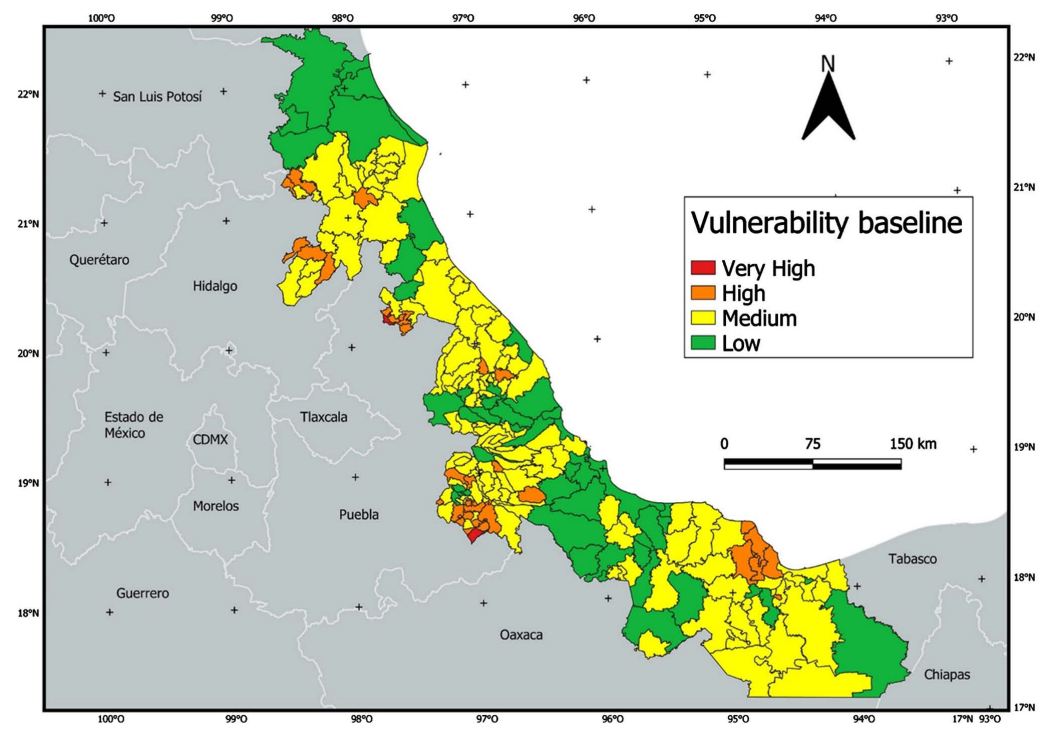

Figure 3. Vulnerability of Veracruz to climate change. 
Table 1. Classification criteria for climate change adaptation projects in the municipalities of Veracruz.

\begin{tabular}{cc}
\hline Vulnerability criteria & Score \\
\hline Very high & 4 \\
High & 3 \\
Medium & 2 \\
Low & 1 \\
Very low & 0 \\
\hline
\end{tabular}

To evaluate the second dimension, or alignment of projects with the national climate change policy of Mexico, the compliance of the projects with two of the five general objectives of the PECC (2014-2018) and a total of 10 strategies was considered. If a project met more than five strategies it was assigned a score of 2 (maximum); if a project met between one and up to five strategies it was assigned a score of 1 (average); if it does not contribute to any strategy, a zero score was assigned.

To evaluate the third, fourth, and fifth dimensions, or the contribution to the increase in the adaptive capacity of the natural sector and socioeconomic sector and the contribution to climate governance, a total of 22 indicators were used, as detailed in Tables 2-4. These are considered management indicators because they reflect the procedures, actions, and programs carried out in the state of Veracruz on behalf of international cooperation agencies. The results and impact indicators were not considered since there is insufficient information is available to obtain reliable results. The evaluation was based on concise questions about specific actions, enabling the degree of adaptation to climate change to be determined.

Using the previously mentioned indicators for each dimension, the evaluation criteria were applied to each of the projects (Table 5), corresponding with a mean score (1) when a project met half of the indicators per sector and a high score (2) when it met half plus one of the indicators:

\section{Normalization of the five dimensions.}

To compare the dimensions, the normalization of the scores of each dimension was carried out considering a maximum score of 100 points, as follows:

- Normalization of dimension per project $=($ value/highest rating $) \times 100$.

- Normalization of dimension for the total of the projects ([sum of all the ratings] $/[$ maximum rating $\times$ number of projects $]) \times 1$.

For visualization, the results were displayed on a radar graph.

\section{Results \& Discussion}

Of a total of 33 projects identified in the state of Veracruz that were financed by international cooperation agencies, 25 are related to climate change adaptation (Table 6). 
Table 2. Indicators selected to evaluate the contribution to the adaptive capacities of the natural sector.

\begin{tabular}{|c|c|c|}
\hline Indicative purpose & Indicator & Questions that define it \\
\hline \multirow{6}{*}{$\begin{array}{l}\text { There are actions } \\
\text { focused on the } \\
\text { ecological functions } \\
\text { of water bodies } \\
\text { and streams. } \\
\text { There are actions } \\
\text { that address soil } \\
\text { quality and health } \\
\text { to address climate } \\
\text { risks in plant cover } \\
\text { and biodiversity. }\end{array}$} & $\begin{array}{c}\text { Restoring } \\
\text { riparian vegetation }\end{array}$ & $\begin{array}{l}\text { Do you consider actions for the } \\
\text { restoration of riparian vegetation, } \\
\text { rehabilitation and sanitation of } \\
\text { streams and water bodies? }\end{array}$ \\
\hline & Basin management & $\begin{array}{l}\text { Do you consider strategies for } \\
\text { watershed and sub-basin management } \\
\text { in the face of the present and future } \\
\text { impacts of climate change? }\end{array}$ \\
\hline & $\begin{array}{l}\text { Soil restoration } \\
\text { and conversion }\end{array}$ & $\begin{array}{l}\text { Do you consider the restoration } \\
\text { and conversion of soils on } \\
\text { degraded surfaces? }\end{array}$ \\
\hline & Reforestation & $\begin{array}{l}\text { Do you consider reforesting actions, } \\
\text { mainly with species that can } \\
\text { better adapt to climate change? }\end{array}$ \\
\hline & $\begin{array}{c}\text { Protection/conservation } \\
\text { of areas }\end{array}$ & $\begin{array}{l}\text { Does it encourage the increase of } \\
\text { Protected Natural Areas and/or the } \\
\text { certification of private conservation } \\
\text { areas? }\end{array}$ \\
\hline & $\begin{array}{l}\text { Establishment of } \\
\text { environmental connectivity } \\
\text { areas and ecological corridors }\end{array}$ & $\begin{array}{l}\text { Does it consider establishing } \\
\text { connectivity areas and biological } \\
\text { corridors that include the present and } \\
\text { future impacts of climate change? }\end{array}$ \\
\hline
\end{tabular}

Table 3. Indicators selected to evaluate the contribution to the adaptive capacities of the socioeconomic sector.

\begin{tabular}{|c|c|c|}
\hline Indicative purpose & Indicator & Questions that define it \\
\hline \multirow{8}{*}{$\begin{array}{l}\text { There are actions for } \\
\text { addressing vector-borne } \\
\text { diseases related to } \\
\text { climate and for the } \\
\text { efficient use of water. } \\
\text { Social vulnerable } \\
\text { groups are considered; } \\
\text { population participate } \\
\text { in territorial planning } \\
\text { to prevent damage, } \\
\text { and is intended to } \\
\text { protect the integrity of } \\
\text { the infrastructure. }\end{array}$} & Vector control & $\begin{array}{l}\text { Does it consider actions for the } \\
\text { control of vectors that transmit } \\
\text { climate-related diseases? }\end{array}$ \\
\hline & Saving water in homes & Does it promote rainwater uptake? \\
\hline & $\begin{array}{l}\text { Community } \\
\text { territorial planning }\end{array}$ & $\begin{array}{l}\text { Do you consider territorial planning } \\
\text { through population participation in } \\
\text { order to identify strengths and risks } \\
\text { to climate impacts? }\end{array}$ \\
\hline & $\begin{array}{l}\text { Attention to social groups } \\
\text { in rural and urban areas }\end{array}$ & $\begin{array}{l}\text { Do you serve rural and urban people } \\
\text { in climate-risk areas? }\end{array}$ \\
\hline & Building planning & $\begin{array}{l}\text { Do you consider actions that promote } \\
\text { the development of an infrastructure } \\
\text { resistant to extreme climate impacts? }\end{array}$ \\
\hline & $\begin{array}{l}\text { Incorporate climate, gender } \\
\text { and human rights approach }\end{array}$ & $\begin{array}{l}\text { Do you consider the gender and } \\
\text { human rights approach? }\end{array}$ \\
\hline & $\begin{array}{l}\text { Install early warning and } \\
\text { risk management systems at } \\
\text { three levels of government }\end{array}$ & $\begin{array}{l}\text { Do you consider early warning and } \\
\text { risk management mechanisms in } \\
\text { the government sectors }\end{array}$ \\
\hline & $\begin{array}{l}\text { Incorporate climate change } \\
\text { criterio into agricultural and } \\
\text { livestock programmes }\end{array}$ & $\begin{array}{l}\text { Do you attend agricultural and } \\
\text { livestock programmes, considering } \\
\text { the effects of the CC? }\end{array}$ \\
\hline
\end{tabular}

Source: Based on Neri and Ávila, 2016; INDC, 2014. 
Table 4. Indicators selected to evaluate the contribution to the adaptive capacities of the climate governance sector.

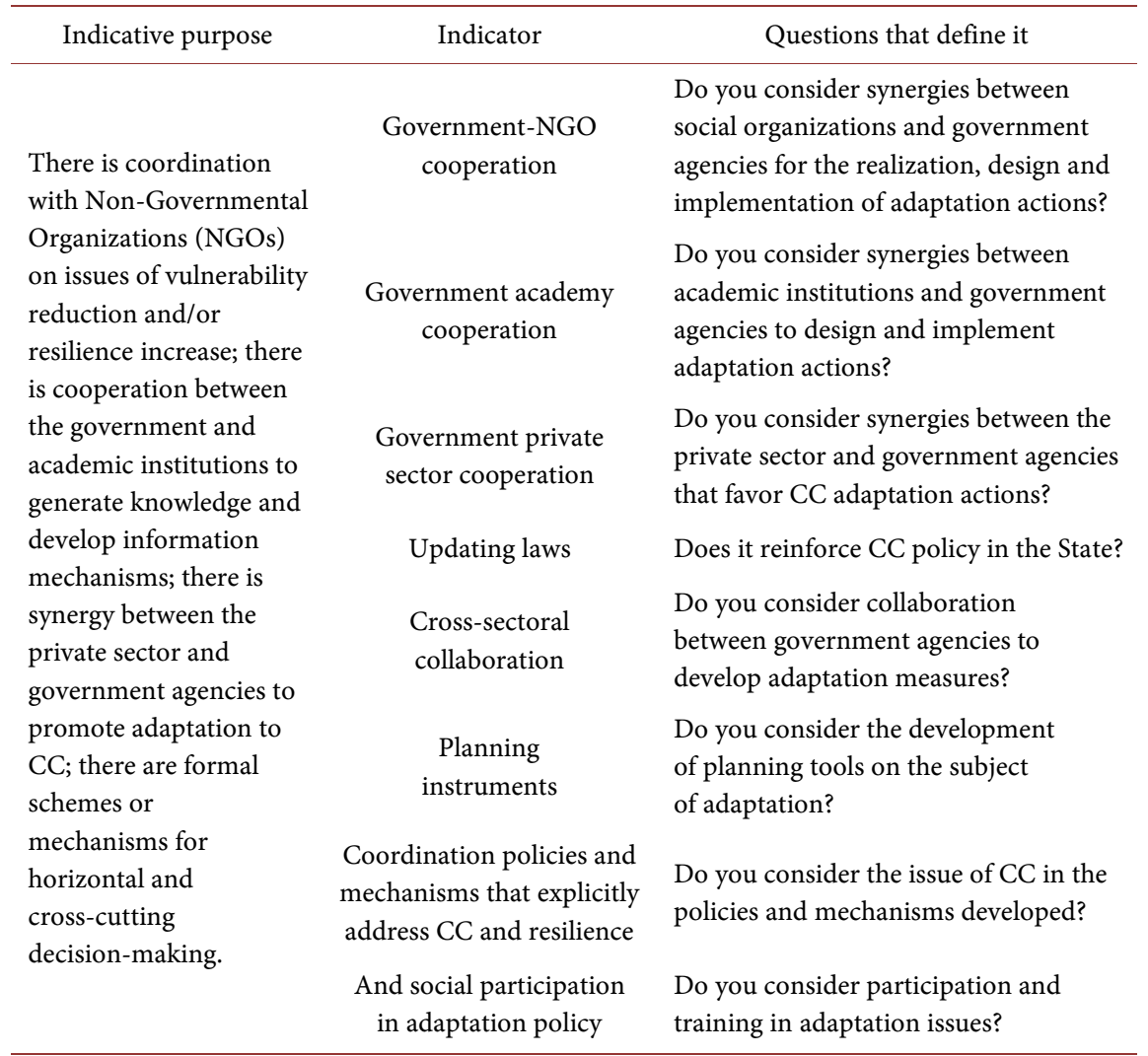

Source: Based on Neri and Ávila, 2016; INDC, 2014; Schwan, 2014.

Table 5. Project classification criteria (natural sector, socio-economic sector, and climate governance).

\begin{tabular}{llcc}
\hline \multicolumn{1}{c}{ Sector } & \multicolumn{1}{c}{ Criteria } & Score & Impact level \\
\hline Socioeconomic sector and governance & More than four indicators & 2 & A lot \\
Natural sector & More than three indicators & 2 & A lot \\
Socio-economic sector and governance & Between one and four indicators & 1 & Little \\
Natural sector & Between one and three indicators & 1 & Little \\
& No indicators & 0 & Nothing \\
\hline
\end{tabular}

Table 6. Type of climate change adaptation projects applied in Veracruz in the 2010-2016 period: (a) biodiversity; (b) government capabilities; (c) productive system; (d) social system; (e) coastal; (f) freshwater and (g) environmental education.

(a)

\footnotetext{
Climate Change Program and Management of Natural Protected Areas

Biodiversity Conservation Program in the Sierra Madre Oriental (CESMO)

Biodiversity studies and strategies

Conservation of coastal basins in the context of climate change

Biodiversity Governance (use and management of biodiversity)

Project to adapt coastal wetlands in the Gulf of Mexico to the impacts of the Climate Change.

Study of the town of Ahuimol in the Chincontepec region
} 
(b)

System of Adaptation Indicators for the State of Veracruz
Sustainable Purchases Criteria for the State of Veracruz
Municipal Climate Action Programs (PACMUN)
State Climate Change Policies
Institutional Capacities and Development of Climate Change Planning and Policy Instruments
Housing and Sustainable Building
Green Budget Index

(c)

Valorization of community sustainable beekeeping

Projects in support of community agencies serving vulnerable people (indigenous women and young people in rural areas)

Improving and dissemination of tropical fruit technology for smallholders

Technical-economic pre-feasibility Study of Compost/Vermicompost Plants

(d)

Improving quality of life with biodigester systems

Wood-saving stoves

Wood-saving stoves to improve health, homes and conserve forests

(e)

Animation and development of the territory by the maritime technopole of Tuxpan, Veracruz

Blue Development Plan of the State of Veracruz

(f)

Sustainable use of water resource ecosystem services

(g)

Senior volunteers on environmental education

The implementation of projects related to climate change adaptation coincides with one of the key conclusions of the 2010 United Nations Conference on Climate Change (COP 16) held in Cancun, Mexico: The same priority should be given to adaptation as well as mitigation. In this conference, the Cancun Adaptation Framework (CAF) was adopted with the objective of reducing the vulnerability of developing countries, which were deemed as the most vulnerable (INECC, 2018).

Sixty-four municipalities were supported by projects, corresponding with 30\% of the state's municipalities (Annex 2). Of these, Chicontepec, Teocelo, Tuxpan, and Xalapa had 3 projects, and Altotonga, Atzalan, Coatepec, Córdoba, San Andrés Tuxtla, and Xico had two projects. However, for those municipalities with more than one project, the projects did span different years and were sponsored by distinct cooperation agencies and sectors. Most of the municipalities that received funding are located in the central part of the state, with $67 \%$, 
and to a lesser extent the southern area, with $14 \%$ and the northern area, with $19 \%$. This geographical distribution of projects contrasts with the fact that in general terms the flood values expected for the state will be higher for the northern part of the state, compared to the rest of the state. This is due to greater extent its geographical location, orientation of the coast and slope of the beach (Silva-Casarín et al., 2018). Due to the increase in sea level projected by general circulation models seawater could enter up to 40 kilometers inland from the coast of the state of Veracruz (Tejeda, 2009). According to Mendoza González et al. (2012), 29 municipalities are located less than $20 \mathrm{~km}$ from the coastal area of Veracruz. Of these 29 municipalities within this coastal area radius, only six are within the 64 municipalities that were supported by funding from international agencies.

The highest number of projects was carried out in 2012 by 10 cooperation agencies. The budget assigned by these agencies was $\$ 1180$ million pesos (approximately $\$ 53,395,000$ U.S. dollars). In this amount, the contribution of the Japanese Agency for International Cooperation is not being considered because it did not provide this data. The agency that made the largest economic contribution ( $\$ 700$ million pesos; about $\$ 31,675,000$ U.S. dollars) was the Global Environment Fund (GEF), followed by the German Agency for Cooperation. The country that financed the most projects (6 in total) was Germany (Figure 4).

The GEF's participation in international cooperation is due to the new group of private sector actors with the greatest influence and financial contributions to global public policies that have their turning point from 2000, with the publication of the Millennium Development Goals, where environmental protection played a central role (Perez and Ayala, 2016).

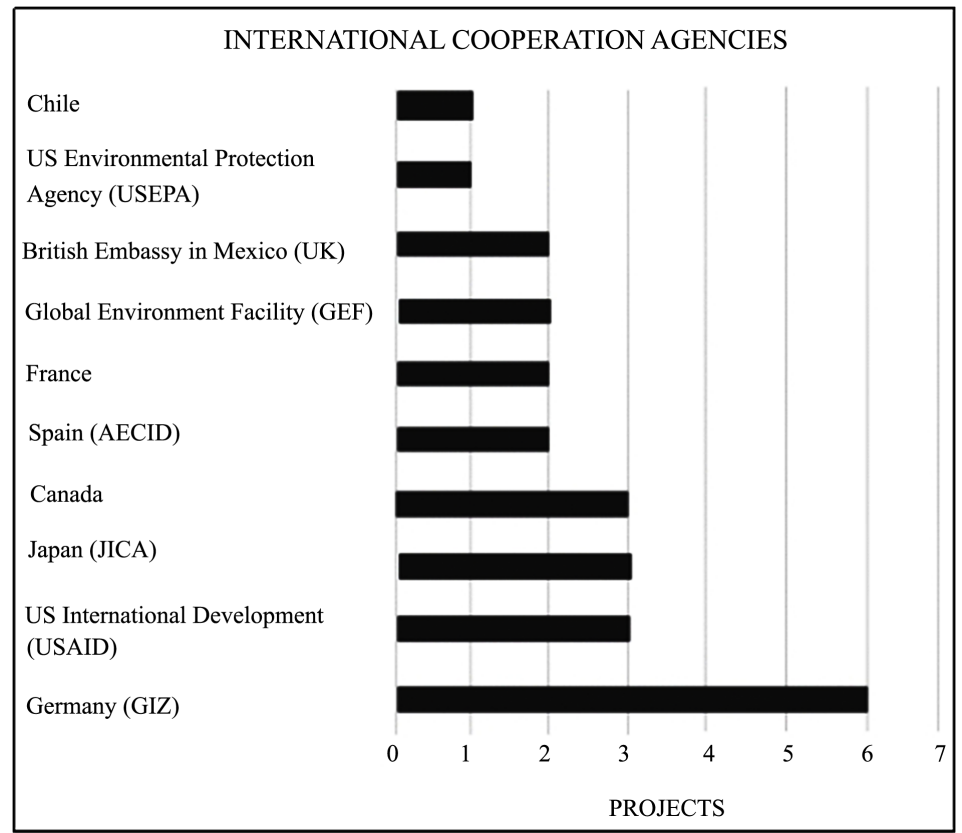

Figure 4. Number of projects for adaptation to climate change in Veracruz in 2010-2016. Source: Designed with own data. 
Covering the cost of adaptation to climate change in developing countries is a challenge for the international community. Actions and adaptive measures in these countries are estimated to require between $\$ 100$ and $\$ 450$ billion dollars (USD) per year. Nonetheless, the sources of financing that have addressed climate change at an international level have focused on mitigation rather than adaptive programs, actions, or instruments. In 2004, only $15 \%$ of the resources allocated to combating climate change were dedicated to adaptation (ODI, 2012). Although this percentage has increased in recent years in response to the increase in international adaptation mechanisms, such as the Adaptation Fund (AF) and the Least Developed Countries Fund (LDCF), the percentage of resources geared to adaptation in 2011 was around 16\% globally (CFU, 2013).

Notably, one of the main results of the United Nations Climate Change Conference (COP 15) held in Copenhagen, Denmark, in 2009, was the participating countries' commitment to mobilize one hundred billion dollars (USD) for climate change by 2020, including a fast-start finance pledge of $\$ 30$ billion dollars (USD) starting in the decade of 2010. However, Latin America receives a relatively small amount of the international funding for climate change mitigation, vulnerability, and adaptation. A total of $\$ 930$ million dollars (USD) was approved for the region between 2004 and 2011 through special climate funds. However, there are bottlenecks in the process, from the conception to execution, as only $\$ 333$ million (USD) was actually disbursed in that timeframe (CFU, 2013). Meanwhile, the Conference of the Parties of the Paris Agreement of 2015 established a new, quantified, and collective target for developing countries of at least $\$ 100$ billion (USD) annually, taking into account their needs and priorities.

As for the case of the Adaptation Fund, Mexico has reportedly accessed funds equal to \$10 million dollars from 2012 to 2016 through the National Implementing Entity, the Mexican Institute of Water Technology (IMTA) (Benet, 2012). Calls for funding issued in 2018 by the Business, Energy, and Industrial Strategy Department of the International Climate Fund (ICF) allocated up to 2 million euros for technical assistance activities in Mexico, specifically in improving energy efficiency (Embajada Británica en México, 2018). Meanwhile, calls for funding emitted by the International Climate Initiative (IKI) offered from 2.5 million to 30 million euros in 2019, with ecosystem-based adaptation as its area of priority (IKI, 2018).

\section{Evaluation of Projects}

The results of the evaluation of the projects (whose titles are listed in Annex 1) under the proposed conceptual model of five dimensions are presented and discussed as following. The scores for each dimension on a scale of 1 to 100 are shown in Table 7.

Three projects stand out (Figure 5): the project for the conservation of coastal basins in the context of climate change financed by the GEF in 2015; the project for the adaptation to climate changes' impacts on coastal wetlands in the Gulf of Mexico, also financed by the GEF through the World Bank in 2011; and finally, 
Table 7. Evaluation of projects according to their five dimensions.

\begin{tabular}{|c|c|c|c|c|c|}
\hline Project & $\begin{array}{l}\text { Vulnerability per } \\
\text { municipalities }\end{array}$ & $\begin{array}{l}\text { Contribution to } \\
\text { the national policy } \\
\text { of climate change }\end{array}$ & $\begin{array}{c}\text { Contribution } \\
\text { to the natural } \\
\text { sector }\end{array}$ & $\begin{array}{l}\text { Contribution to } \\
\text { the socioeconomic } \\
\text { sector }\end{array}$ & $\begin{array}{c}\text { Contribution } \\
\text { to climate } \\
\text { governance }\end{array}$ \\
\hline 1 & 100 & 50 & 50 & 0 & 50 \\
\hline 2 & 100 & 50 & 50 & 50 & 50 \\
\hline 3 & 100 & 50 & 0 & 0 & 0 \\
\hline 4 & 25 & 50 & 0 & 0 & 0 \\
\hline 5 & 25 & 50 & 0 & 0 & 50 \\
\hline 6 & 50 & 100 & 100 & 50 & 100 \\
\hline 7 & 25 & 50 & 0 & 0 & 0 \\
\hline 8 & 50 & 50 & 50 & 0 & 50 \\
\hline 9 & 100 & 0 & 0 & 0 & 0 \\
\hline 10 & 25 & 50 & 0 & 50 & 50 \\
\hline 11 & 100 & 50 & 0 & 0 & 50 \\
\hline 12 & 100 & 50 & 0 & 0 & 50 \\
\hline 13 & 50 & 100 & 50 & 0 & 50 \\
\hline 14 & 50 & 0 & 0 & 0 & 50 \\
\hline 15 & 25 & 100 & 50 & 50 & 100 \\
\hline 16 & 50 & 50 & 50 & 50 & 50 \\
\hline 17 & 50 & 50 & 0 & 50 & 50 \\
\hline 18 & 75 & 50 & 0 & 0 & 50 \\
\hline 19 & 100 & 0 & 0 & 0 & 50 \\
\hline 20 & 100 & 0 & 0 & 0 & 50 \\
\hline 21 & 100 & 0 & 0 & 0 & 50 \\
\hline 22 & 100 & 50 & 0 & 0 & 0 \\
\hline 23 & 100 & 50 & 0 & 0 & 0 \\
\hline 24 & 50 & 0 & 0 & 0 & 0 \\
\hline 25 & 50 & 50 & 0 & 0 & 0 \\
\hline TOTAL RATING & 1700 & 1100 & 400 & 300 & 950 \\
\hline $\begin{array}{l}\text { MAXIMUM RATING * } \\
\text { NUM. PROJECTS }\end{array}$ & 2500 & 2500 & 2500 & 2500 & 2500 \\
\hline $\begin{array}{c}\text { STANDARDIZED } \\
\text { RATING }\end{array}$ & 68 & 44 & 16 & 12 & 38 \\
\hline
\end{tabular}

the program for the conservation of biodiversity in the eastern Sierra Madre financed by the GIZ in 2012.

The overall results of the 25 evaluated projects in terms of the evaluated dimensions are summarized in Figure 6.

The evaluation of the first dimension (vulnerability of the municipalities to climate change) received the highest overall score of 68 points. This was due to 


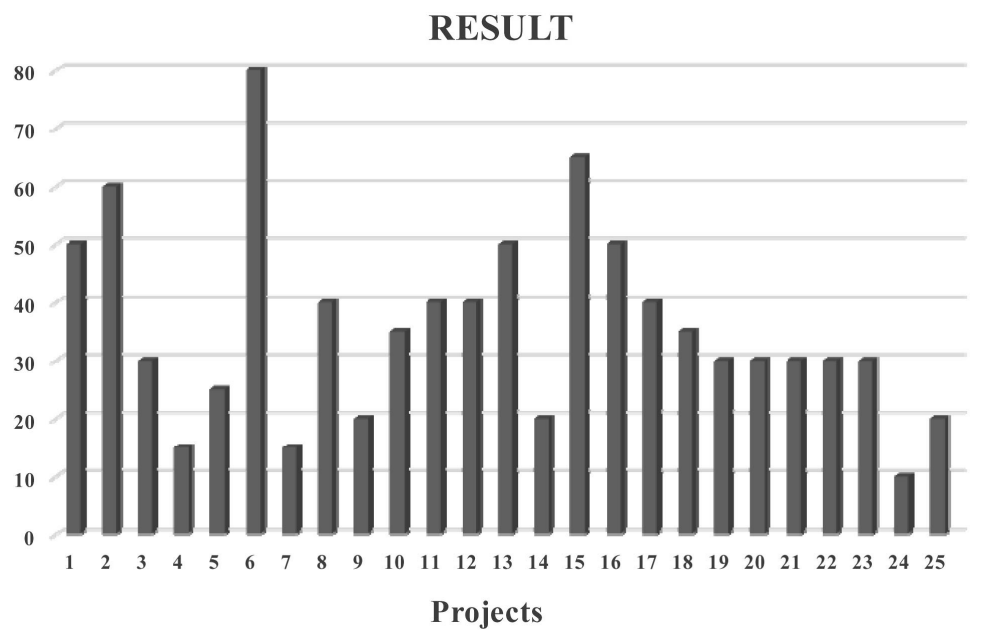

Figure 5. Comparative results of each project evaluated according to five dimensions.

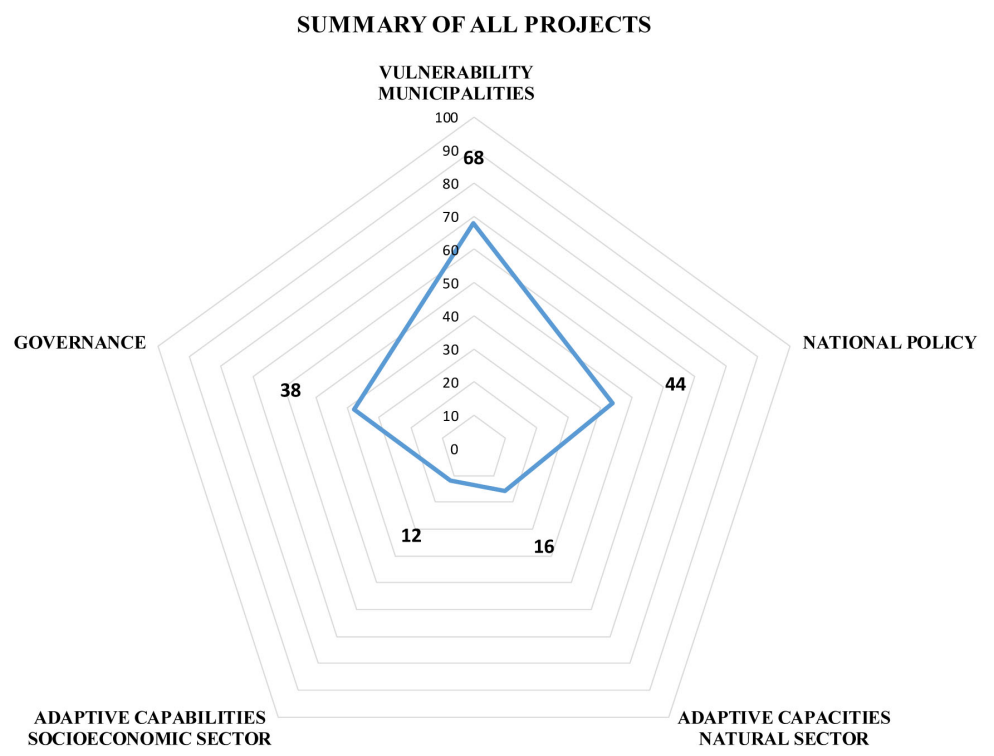

Figure 6. Results of the evaluation of 25 climate change adaptation projects.

the normalization of the data and the inclusion of projects that impacted the entire state $(44 \%$ of the projects correspond with planning documents, decision making, planning instruments, research documents, and law and public policies). To reduce vulnerability, Mercer (2010) noted that the capacities needed to understand the implications of climate change were being created through the use of information and research studies.

The application of climate change projects and level of vulnerability of the 64 municipalities where projects were implemented, corresponding with $30 \%$ of the state's total municipalities, are visualized in Figure 7. It is evidenced that the adaptation projects do not always correspond with the highly vulnerable municipalities but are also implemented in municipalities with medium vulnerability.

According to Imbach et al. (2015), vulnerability analysis is essential to identify the sites most affected by a phenomenon, such as climate change (e.g., heat 


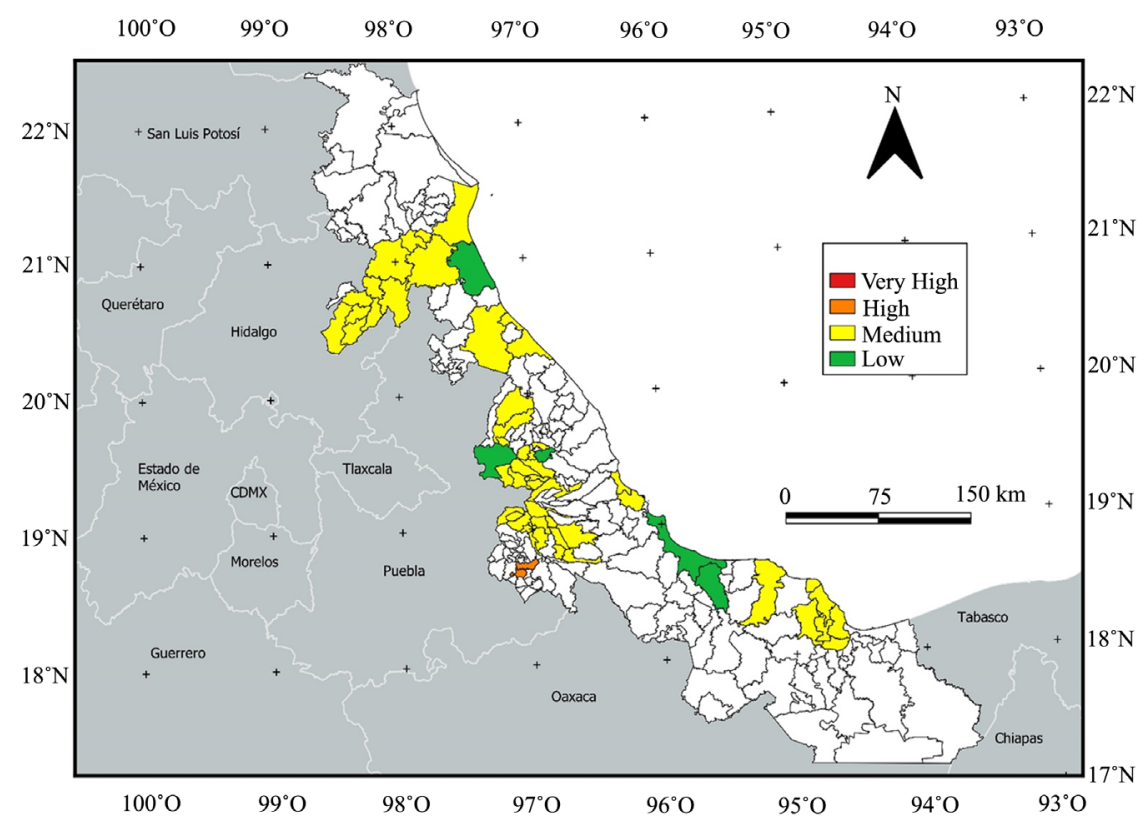

Figure 7. Application of climate change adaptation projects in Veracruz municipalities by level of vulnerability. Source: Own elaboration, adapted from Monterroso et al., 2014.

waves and floods), in order to prioritize the allocation of resources. In addition, it can help to understand the behavior of socio-environmental systems (community and infrastructure) and their attributes (e.g., health and economy). In response to vulnerability, it is necessary to define possible adaptation measures and to monitor the effectiveness of currently implemented measures. The suggested measures must consider both the biophysical and social components of a system to be successful (Delgado, Luca. \& Vázquez, 2015). Finally, international cooperation agencies (in coordination with the organizations of the implementing state) should allocate resources to the areas of highest priority.

In regard to the second dimension, or contribution to national policy, a score of 44 was reached, indicating that less than half of the executed projects are aligned with the national strategies outlined in the PECC 2014-2018. This program is Mexico's main public policy instrument for addressing climate change. It aims to promote, regulate, and enable the implementation of the national climate change policy and also suggests adaptation and mitigation actions based on a long-term, systematic, decentralized, participatory, and comprehensive approach. Martínez, Muñoz, and Ojeda (2014) mention that it is difficult to measure the impact of the PECC 2014-2018 in Mexico, including its effectiveness as a strategic tool or support for real interventions. However, one of the lessons of the program is that the implementation of climate change policies poses a double challenge. First, the implementation of such policies requires clarity and coordination among institutions that extend beyond a sectorial approach. Second, it forces regions to rethink themselves as complex territorial units given that the implementation of actions and their effectiveness requires a bottom-up approach and the mobilization of existing resources at local levels, including lo- 
cal political will and social pressure, in order to achieve medium- and long-term objectives.

For this reason, alignment to the objectives of the program is crucial in order to carry out priority mitigation and adaptation measures. A unified response is necessary in order to channel international support and jointly face the vulnerability and risks to which the country is subjected. It is also necessary to contemplate the stipulations of new laws, such as the Climate Change General Law, which was last updated on July 13th, 2018. It describes the baseline measures that Mexico should meet to fulfill the stipulations of the Paris Agreement and defines the Intended Nationally Determined Contribution (NDC) toward the reduction in GHGs in order to achieve the goals of the agreement. In addition, it mandated the creation of a National Adaptation Program and the development of an early warning system to reduce social vulnerability to extreme weather events (DOF, 2018).

The contribution to the third dimension, or adaptive capacity of the natural sector, received a score of 16 points. This is due to the approach of the evaluated projects. They were not carried out in the upper, middle, or lower basins of the state's priority areas, nor did they consider native species. Furthermore, they disregarded the conservation of coastal systems. In terms of vulnerability, these areas are where the state of Veracruz requires the most attention.

Llano and Fernández (2017) argued that the adoption of transversal policies in territorial planning is urgent in Mexico in order to promote the conservation and sustainable use of natural capital. In this regard, sustainability can potentially be regarded as a strategic, guiding axis. As part of such measures and for the evaluation of progress, it is necessary to set specific quantitative and temporal goals and to bolster regulatory, economic, and market instruments that value biodiversity.

The fourth dimension, or contribution to the adaptive capacity of the socioeconomic sector, received a score of 12 points. This sector received the lowest score due to the complexity of the factors involved: it is safe to assume that there are many issues to attend to in this sector. The focus on the need for social changes has garnered momentum in contemporary societies due to, for example, the increasing demand for energy and basic resources. Without a doubt, this sector requires a further detailed analysis given the innumerable indicators. Its estimation is important because climate change does not occur independently of socioeconomic processes. The link between the former and the policies that regulate and guide the latter will improve the quality of life of the population and promote economic growth. In addition, these policies must be articulated and respond to a global strategy for sustainable development (SEMARNAT, 2012).

At a governance level, a score of 38 points was obtained. Around half of the executed projects collaborated with or were carried out by different entities, such as civil associations, academia, and government. In some cases, the inclusion of social groups occurred through local training workshops. As Demares (2016) pointed out, global climate governance is fragmented but, at the same time, de- 
pendent on local action because the solutions to climate change are ultimately local. In this context, the generation of information and citizen participation are of the essence and represent transversal instruments that can be used in strategic combination with other management tools. In addition, McCarney (2006) stressed that each city faces unique challenges in addressing climate risks, and solutions must be adapted to their own specific context based on a local governance approach. The success of such efforts is related to the governance capacity of cities which, if weak or limited, signifies that the capacity to implement programmatic measures for mitigation or adaptation to climate change is reduced. Likewise, efficient financing is a basic requirement for enhanced governance in cities.

In summary, the overall results of the five analyzed dimensions are not at all flattering. On one hand, they reveal that it is necessary to construct regional adaptation strategies that contemplate actions on behalf of government authorities, the private sector, and civil society. Imbach et al. (2015) suggest that local adaptation strategies to climate change be carried out according to precise steps and, firstly, by defining the scope of the strategy and the characteristics of the territory. Also, a vulnerability analysis is necessary. Ultimately, these steps should culminate in a portfolio of investment projects that would together lead to an increase in the natural, social, and economic adaptive capacities of a region or system. A stronger focus on effective adaption will support developing countries in their quest to achieve climate-resilient sustainable development (Fritzsche et al., 2014). Given the aforementioned, it is importance to identify the priorities for adaptation in the specific context, sector, or region in question, involving different actors and, above all, to pursue influence in public policy actions at a given time (Zorrilla \& Altamirano, 2015).

It is important to note that the results obtained herein were based on the indicators considered suitable for the case study. Quiroga (2009) highlighted that indicators ideally constitute a system of clear and timely signals about a determined environmental process, constituting a system of select information to evaluate progress in certain matters, and that not all data are a valid input, which is why it is crucial to certify their origin.

Finally, it is considered that the perception of the experts reinforces the evaluation of the indicators. Eighty-seven percent of those interviewed agreed that international cooperation projects have in fact contributed to the increase of adaptive capacities in the state of Veracruz. They recognize that the issue is complex, as the intricacies of both local and regional climate changes must be understood but, in order to face climate change, the risks must be addressed comprehensively with a territorial and systematic vision. The use of international and national economic resources must be efficient, especially in cases where adaptation processes are gradual. The general perception was that international financing can increase, directly or indirectly, the adaptive capacity of different sectors to future climate variability. 
At the national level, planning instruments with a territorial focus are important because they enable better decision making in favor of sustainability and can attend to priority zones for conservation in order to make ecosystems and biodiversity more resilient and, lastly, can strengthen the capacities of the governmental and productive sectors. This reinforces Mercer's findings (2010) in regard to the use of information and results from research to further comprehend the consequences of climate change.

\section{Mexican Experience in Context}

International cooperation has evolved from the mere transfer of resources between two or more international actors, to the inclusion of criteria of equity, sustainability and co-responsibility to developing countries, so that they could reach a high level of human development (Fernandez and Pieske, 2004; Marcellesi, 2012; Duarte and González, 2014). However, it is fair to recognize that international aid is governed by geopolitical parameters that have more to do with the interests of the donor than with those of the recipient (Llistar, 2009). This, despite, in economic terms, climate change represents the biggest and most widespread market failure ever seen in the world, the greatest negative externality of the system, as it affects not only who causes the damage, but also impacts other economies and other generations (Stern, 2006).

The Mexican case illustrates that success in adaptation measures depends not only on financial resources, but also largely on the participation of civil society in its design (Landa, Ávila and Hernández, 2010). Since even though this country has developed institutions to regulate and administer international support, such as the Agency for International Cooperation for Development (AMEXCID), and the International Cooperation for Development Act (LCID, 2011), this agency has not taken a proactive role in registering and guiding international funds towards the needs of the recipient communities.

\section{Conclusion}

In a timeframe of seven years (2010-2016), 25 climate change adaptation projects were implemented in the state of Veracruz through international cooperation. These were executed over $30 \%$ of the territory, with an impact on $45 \%$ of the total population. The budget assigned by these agencies was $\$ 1.18$ billion pesos, and the country that financed the most projects was Germany. However, the projects were not always implemented in highly vulnerable municipalities, but rather, mostly in areas with a medium degree of vulnerability. The general results of the contribution of the projects toward the five analyzed dimensions are not flattering. Regarding the contribution to climate change policies in Mexico, less than half of the evaluated projects are aligned with the national strategies outlined in the PECC 2014-2018. As for the natural sector, the approaches of the evaluated projects are not focused on priority areas of the upper, middle, or lower basins of the state, nor are they oriented toward the conservation of coast- 
al systems, which require the most attention given their vulnerability. As for the socioeconomic sector, despite the overall low score, several projects that aimed to carry out local actions stand out, including some related to community territorial planning or that attended to social groups in rural and urban zones. Finally, in regard to climate governance, different governmental entities participated in approximately half of the executed projects, such as civil associations, academia, and government, and in some cases, different social groups were included in training workshops on local production systems.

This study offers a general overview of the resources received in the state of Veracruz from international cooperation efforts. Without a doubt, it is crucial to delve deeper into each of the implemented projects to assess their impact on territory and society.

\section{Conflicts of Interest}

The authors declare no conflicts of interest regarding the publication of this paper.

\section{References}

Adger, W. N., \& Kelly, P. M. (1999). Social Vulnerability to Climate Change and the Architecture of Entitlements. Mitigation and Adaptation Strategies for Global Change, 4, 253-266. https://doi.org/10.1023/A:1009601904210

Ashan, N., \& Warner, J. (2014). The Socioeconomic Vulnerability Index: A Pragmatic Approach for Assessing Climate Change Led Risk. A Case Study in the South-Western Coastal Bangladesh. International Journal of Disaster Risk Reduction, 8, 32-49. https://doi.org/10.1016/j.ijdrr.2013.12.009

Benet, K. R. G. (2012). Evaluación de esquemas de financiamiento existentes a nivel internacional y su impacto en los esfuerzos de reducción de Vulnerabilidad y Adaptación al Cambio Climático en países en desarrollo en Latinoamérica y particularmente en México. México: Instituto Nacional de Ecología y Cambio Climático (INECC), Programa de las Naciones Unidas para el Desarrollo (PNUD).

Bronfman, M., \& Díaz Polanco, J. (2003). La cooperación técnica internacional y las políticas de salud. Ciência e Saúde Coletiva, 8, 227-241. https://doi.org/10.1590/S1413-81232003000100016

Buob, S., \& Gunter, S. (2011). To Mitigate or to Adapt: How to Confront Global Climate Change. European Journal of Political Economy, 27, 1-16. https://doi.org/10.1016/j.ejpoleco.2010.05.001

CFU, Climate Funds Update (2013). Global Climate Finance Data. http://www.climatefundsupdate.org/data

CONABIO, Comisión Nacional para el Conocimiento y Uso de la Biodiversidad (2013). Estrategia para la conservación y uso sustentable de la biodiversidad del Estado de Veracruz. México: CONABIO.

CONEVAL, Consejo Nacional de Evaluación de la Política de Desarrollo Social (2016). Índice de Rezago Social. Presentación de Resultados. México: CONEVAL.

CONEVAL, Consejo Nacional de Evaluación de la Política de Desarrollo Social (2018). Informe de evaluación de la política de desarrollo social 2018. México: CONEVAL.

Debela, N., McNeil, D., Bridle, K., \& Mohammed, C. (2019). Adaptation to Climate 
Change in the Pastoral and Agropastoral Systems of Borana, South Ethiopia: Options and Barriers. American Journal of Climate Change, 8, 40-60.

https://doi.org/10.4236/ajcc.2019.81003

Delgado, R. G. C., Luca, Z. A. D., \& Vázquez, Z. V. (2015). Adaptación y mitigación urbana del cambio climático en México. México: Universidad Nacional Autónoma de México. Centro de investigaciones interdisciplinarias en ciencias y humanidades, programa de investigación en cambio climático.

Demares, M. (2016). La importancia de la gobernanza climática global y de la vigésimo primera Conferencia de las Partes en la lucha contra el Cambio Climático. Observatorio Medioambiental, 19, 55-69. https://doi.org/10.5209/OBMD.54158

DOF, Diario Oficial de la Federación (2018). Decreto por el que se reforman y adicionan diversas disposiciones de la Ley General de Cambio Climático. México: Secretaría de Gobernación.

Duarte, L. K., \& González, V. (2014). Origen y evolución de la cooperación internacional para el desarrollo. Panorama, 8, 117-131. https://doi.org/10.15765/pnrm.v8i15.554

Eckstein, D., Künzel, V., \& Schäfer, L. (2017). Índice de Riesgo Climático Global 2018. Bonn: Germanwatch Ev.

Embajada Británica en México (2018). Convocatoria de propuestas para el Programa de Asistencia Técnica de México.

https://www.gov.uk/government/news/call-for-proposals-for-mexicos-technical-assista nce-programme

Evans, J. W., \& Davies, R. (2015). Too Global to Fail: The World Bank at the Intersection of National and Global Public Policy in 2025. Washington DC: World Bank Group. https://doi.org/10.1596/978-1-4648-0307-9

Fernandez, N., \& Pieske, V. (2004). Informe Especial. Cooperación Internacional Para Municipios. Buenos Aíres: Fundación Grupo INNOVA y Fundación CIPPEC.

Fritzsche, K., Schneiderbauer, S., Bubeck, P., Kienberger, S., Buth, M., Zebisch, M., \& Kahlenborn, W. (2014). The Vulnerability Sourcebook Concept and Guidelines for Standardized Vulnerability Assessments. Bonn and Eschborn: Deutsche Gesellschaft für Internationale Zusammenarbeit (GIZ).

Gobierno de la República Mexicana Mexicana (2014). Versión de Difusión del Programa Especial de Cambio Climático 2014-2018. México: Gobierno de la República Mexicana Mexicana.

Goeminne, G., \& Paredis, E. (2008). The Concept of Ecological Debt: An Environmental Justice Approach to Sustainability, Calling for Radical Transitions in Industrialized Countries. 7th Global Conference on Environmental Justice and Global Citizenship, Oxford, July.

IKI, Iniciativa Climática Internacional (2018). https://www.international-climate-initiative.com/en/project-funding/information-forapplicants

Imbach, A. C., Bouroncle, B., Díaz, A., Zamora, A., Urueña, O., Aragón, O., Colque, P., Rosales, B. L., Prado, P., Girón, E., Imbach, P., \& Medellín, C. (2015). La construcción de estrategias locales de adaptación al cambio climático: Una propuesta desde el enfoque de medios de vida. Turrialba: Centro Agronómico Tropical de Investigación y enseñanza (CATIE).

INDC, Contribuciones Previstas y Determinadas a Nivel Nacional (2014). Compromisos de mitigación y adaptación ante el cambio climático para el periodo 2020-2030. México: Gobierno de la República Mexicana.

INECC, Instituto Nacional de Cambio Climático (2018). 
http://www.gob.mx/inecc/acciones-y-programas/adaptacion-al-cambio-climatico-78748

INEGI, Instituto Nacional de Estadística y Geografía (2015). México en cifras INEGI. México. http://www.beta.inegi.org.mx/app/areasgeograficas/\#

INEGI, Instituto Nacional de Estadística y Geografía (2016). Anuario estadístico y geográfico de Veracruz de Ignacio de la Llave 2016. México: INEGI.

Landa, R., Ávila, F. B., \& Hernández, M. (2010). Cambio climático y desarrollo sustentable para América Latina y el Caribe. Conocer para comunicar. http://www.keneamazon.net/Documents/Publications/Virtual-Library/Impacto/105.pdf

LCID, Ley de Cooperación Internacional para el Desarrollo (2011). Diario Oficial de la Federación. Cámara De Diputados del H. Congreso De La Unión. Última reforma publicada DOF 17-12-2015. México.

Llano, M., \& Fernández, H. (2017). Análisis y propuestas para la conservación de la biodiversidad en México 1995-2017.

https://agua.org.mx/biblioteca/analisis-propuestas-la-conservacion-la-biodiversidad-en -mexico-1995-2017

Llistar, B. D. (2009). Anticooperacion: Interferencias Norte-Sur. Los problemas del Sur Global no se resuelven con mas ayuda internacional. El Observatori del Deute en la Globalitzacio de la Catedra UNESCO. Barcelona: Icaria.

Maldonado, G. A. L., \& González, G. E. J. (2013). De la resiliencia comunitaria a la ciudadanía ambiental. El caso de tres localidades en Veracruz, México. Integra Educativa, 6, 14-28.

Marcellesi, F. (2012). Cooperación al posdesarrollo: Bases teóricas para la transformación ecológica de la cooperación al desarrollo. Bilbao: Bakeaz.

Martínez, F. J. L., Tijerina, C. L., Arteaga, R. R., Vázquez, P. M. A., \& Becerril, R. A. E. (2007). Determinación de zonas agroclimáticas para la producción de mango (Mangifera indica L. "Manila”) en Veracruz, México. Investigaciones geográficas, 63, 17-35.

Martínez, P. S., Muñoz, M. G., \& Ojeda, R. L. (2014). La coordinación multiinstitucional y las fronteras como un reto a las políticas de cambio climático. In N. Oddone, \& $\mathrm{H}$. Rodríguez (Eds.), Municipios y Cambio Climático: Hacia la construcción de una agenda de paradiplomacia ambiental (pp. 550-525). Granada: Unión Iberoamericana de Municipalistas.

McCarney, P. L. (2006). Our Future: Sustainable Cities. Turning Ideas into Action. Background Paper, Nairobi: World Urban Forum UN-HABITAT.

Mendoza González, G., Martínez, M. L., Lithgow, D., Pérez-Maqueo, O., \& Simonin, P. (2012). Land Use Change and Its Effects on the Value of Ecosystem Services along the Coast of the Gulf of Mexico. Ecological Economics, 82, 23-32. https://doi.org/10.1016/j.ecolecon.2012.07.018

Mercer, J. (2010). Reducción del riesgo de desastres o adaptación al cambio climático: Estamos reinventando la rueda? Journal of International Development, 22, 247-264.

Miller, K., Harley, M., \& Kent, N. (2012). Climate Change Adaptation-Related Indicators. Edinburgh: Sniffer.

Miller, S., Yoon, S. W., \& Yu, B. K. (2013). Vulnerability Indicators of Adaptation to Climate Change and Policy Implications for IDB Projects. Washington DC: Inter-American Development Bank, Department of Research and Chief Economist Policy Brief.

Monterroso, R. A., Fernández, E. A., Trejo, V. R. I., Conde, A. A. C., Escandón, C. J., Villers, R. L., \& Gay, G. C. (2014). Vulnerabilidad y adaptación a los efectos del cambio climático en México. Centro de Ciencias de la Atmósfera. Programa de Investigación en Cambio Climático. México: Universidad Nacional Autónoma de México. 
Mussetta, P., Barrientos, M. J., Acevedo, E., Turbay, S., \& Ocampo, O. (2017). Vulnerabilidad al cambio climático: Dificultades en el uso de indicadores en dos cuencas de Colombia y Argentina. EMPIRIA: Revista De Metodología De Ciencias Sociales, 1, 119-147. https://doi.org/10.5944/empiria.36.2017.17862

Neil, A. W. (2006). Vulnerability. Global Environmental Change, 16, 268-281. https://doi.org/10.1016/j.gloenvcha.2006.02.006

Neri, C., \& Ávila, B. (2016). Sistema de indicadores para el estado de Veracruz. Cooperación técnica entre México y Alemania. México: Gobierno del Estado de Veracruz.

O’Brien, K., Leichenko, R., Kelkar, U., Venema, H., Aandahl, G., Tompkins, H., Javed, A., Bhadwal, S., Barg, S., Nygaard, L., \& West, J. (2004). Mapping Multiple Stressors: Climate Change and Economic Globalization in India. Global Environmental Change, 14, 303-313. https://doi.org/10.1016/j.gloenvcha.2004.01.001

ODI, Overseas Development Institute (2012). Climate Finance Thematic Briefing: Adaptation Finance. Climate Funds Update. Reino Unido. https://www.odi.org/publications/4933-climate-funds-update-climate-finance-policy-b riefs

Ortiz, L. L., Briseño, A., Granados, B. A., Salas, M. D., \& Jiménez, B. L. M. (2010). Atlas del patrimonio natural, histórico y cultural de Veracruz. In E. Florescano, \& J. Ortiz Escamilla (Eds.), Zona Costera (pp. 123-146). México: Comisión del Estado de Veracruz para la Conmemoración de la Independencia Nacional y la Revolución Mexicana.

Paredis, E., Goeminne, G., Vanhove, W., Maes, F., \& Lambrecht, J. (2008). The Concept of Ecological Debt: Its Meaning and Applicability in International Policy. Ghent: Academia Press.

Perez, J., \& Ayala, C. (2016). Diagnóstico de la cooperación internacional para el desarrollo mexicana y su andamiaje institucional actual. Papeles de Europa, 29, 31-50. https://doi.org/10.5209/rev_PADE.2016.v29.n1.54074

Piñar, A. (2012). Gobernanza ambiental en destinos turísticos de áreas naturales protegidas. Reservas de la Biósfera Los Tuxtlas (Veracruz, México) y Sierra Nevada-La Alpujarra (Andalucia, España). Xalapa: IETEC, Arana editores y Colegio de Veracruz.

PNUD, Programa de las Naciones Unidas para el Desarrollo (2010). A Toolkit for Designing Climate Change Adaptation Initiatives. New York: UNDP and Bureau of Development Policy.

Quiroga, M. R. (2009). Guía metodológica para desarrollar indicadores ambientales y de desarrollo sostenible en países de América Latina y el Caribe. Santiago: Naciones Unidas.

Requena, C. (2014). Gobernanza. Reto en la relación Estado-Sociedad. México: LID Editorial Mexicana.

Schwan, S. (2014). Repositorio de indicadores de adaptación. Ginebra: Deutsche Gesellschaft für Internationale Zusammenarbeit (GIZ).

SEMARNAT, Secretaría de Medio Ambiente y Recursos Naturales (2012). Adaptación al cambio climático en México: Visión, elementos y criterios para la toma de decisiones. México: SEMARNAT.

Silva-Casarín, R., Moreno-Casasola, P., Martínez, M. L., Mendoza, B. E., López-Portillo, J., Lithgow, D., Vázquez, G., Martínez, M. R. E., Monroy, I. R., Cáceres, P. J. I., Ramírez, H. A., \& Boy, T. M. (2018). La zona costera del estado de Veracruz: Clima marítimo, medio físico y medio biótico. México: Instituto de Ecología A. C.

Stern, N. (2006). Stern Review on the Economics of Climate Change. 
http://www.sternreview.org.uk

Stern, P., Young, O., \& Druckman, D. (1992). Global Environmental Change: Understanding the Human Dimensions. Washington DC: National Academy Press.

Tejeda, M. A. (2009). Programa Veracruzano ante el Cambio Climático. Versión corregida y aumentada a partir de la consulta pública. México: Universidad Veracruzana-INECCEmbajada Británica en México-Centro de Ciencias de la Atmósfera de la UNAM.

Warlenius, R. (2016). Core and Periphery in the Early Modern World System. A Time-Space Appropriation Assessment. In A. Jarrick, J. Myrdal, \& M. Wallenberg Bondesson (Eds.), Methods in Global History. A Critical Approach (pp. 185-225). Lund: Nordic Academic Press. https://doi.org/10.21525/kriterium.2.g

Zorrilla, R. M., \& Altamirano, M. A. (2015). Hacia la construcción de un sistema de indicadores para la adaptación en México: Propuesta metodológica y matriz de indicadores. Informe Final. México: Deutsche Gesellschaft für Internationale Zusammenarbeit (GIZ). 


\section{Annex 1: List of the Titles of the Evaluated Projects}

1) Programa cambio climático y gestión de áreas naturales protegidas.

2) Programa de conservación de biodiversidad en la sierra madre oriental.

3) Estudios y estrategias de biodiversidad de Chiapas, Puebla y Veracruz.

4) Animación y desarrollo del territorio por el tecnopolo marítimo de Tuxpan, Veracruz.

5) Plan de desarrollo azul del Estado de Veracruz.

6) Conservación de Cuencas Costeras en el Contexto de Cambio Climático.

7) Uso sustentable de los servicios ecosistémicos del recurso hídrico.

8) Gobernanza de la biodiversidad: Participación justa y equitativa de los beneficios que se deriven del uso y manejo de la diversidad biológica.

9) Valorización de la apicultura sostenible comunitaria.

10) Vivienda y edificación sustentable.

11) Sistema de Indicadores de Adaptación para el Estado de Veracruz.

12) Criterios de compras sustentables para el Estado de Veracruz.

13) Programas de Acción Climática Municipal (PACMUN).

14) Estudio de prefactibilidad técnico-económica de plantas de composta/vermicomposta en dos zonas del estado de Veracruz.

15) Proyecto de adaptación de humedales costeros del Golfo de México ante los impactos del cambio climático.

16) Mejorando la calidad de vida con sistemas biodigestores.

17) Construyendo 24 estufas ahorradoras de leña en 4 comunidades de Veracruz.

18) Construyendo estufas ahorradoras de leña para mejorar la salud, los hogares y conservar los bosques.

19) Políticas estatales en materia de cambio climático.

20) Capacidades institucionales y desarrollo de instrumentos de planeación y de política en materia de cambio climático en las 32 entidades federativas (comprende los 31 estados y el distrito federal) y sobre el Sistema Nacional De Cambio Climático (SINACC).

21) Índice de presupuestos verdes: análisis de presupuesto de egresos que incentive acciones ambientales en sectores estratégicos de competencia estatal.

22) Proyecto en apoyo a organismos comunitarios que atienden a población vulnerable, sustancialmente mujeres y jóvenes indígenas en el medio rural, en los estados de México, Puebla y Veracruz.

23) Mejoramiento y difusión de tecnología de frutas tropicales para los pequeños productores en el Estado de Veracruz.

24) Cooperación técnica, a través del programa de envío de voluntarios senior, en el tema de educación ambiental.

25) Estudio Etnobotánico de la localidad de Ahuimol en la región de Chincontepec, Veracruz. 
Annex 2: Municipalities of the State of Veracruz with an International Cooperation Project in the 2010-2016 Period

\begin{tabular}{|c|c|c|c|}
\hline Número & Municipio & Número & Municipio \\
\hline 1 & Acajete & 36 & Papantla \\
\hline 2 & Alamo Temapache & 37 & Paso del Macho \\
\hline 3 & Alpatlahuac & 38 & Perote \\
\hline 4 & Altotonga & 39 & Poza Rica \\
\hline 5 & Alvarado & 40 & Río Blanco \\
\hline 6 & Amatlan De Los Reyes & 41 & San Andres Tuxtla \\
\hline 7 & Atlahuilco & 42 & Soteapan \\
\hline 8 & Atoyac & 43 & Tamiahua \\
\hline 9 & Atzalan & 44 & Tatahuicapan \\
\hline 10 & Ayahualulco & 45 & Tecolutla \\
\hline 11 & Banderilla & 46 & Teocelo \\
\hline 12 & Benito Juarez & 47 & Tepatlaxco \\
\hline 13 & Calcahualco & 48 & Tepetzintla \\
\hline 14 & Camerino & 49 & Tequila \\
\hline 15 & Cerro Azul & 50 & Texcatepec \\
\hline 16 & Chicontepec & 51 & Tlachichilco \\
\hline 17 & Chinameca & 52 & Tlacotalpan \\
\hline 18 & Chocaman & 53 & Tlalnelhuayocan \\
\hline 19 & Coatepec & 54 & Tlaltetela \\
\hline 20 & Cordoba & 55 & Tlilapan \\
\hline 21 & Cosautlan de Carvajal & 56 & Tomatlan \\
\hline 22 & Coscomatepec & 57 & Tuxpan \\
\hline 23 & Cuitlahuac & 58 & Veracruz \\
\hline 24 & Fortin & 59 & Villa Aldama \\
\hline 25 & Huatusco & 60 & Xalapa \\
\hline 26 & Huayacocotla & 61 & Xico \\
\hline 27 & Ixhuacan de Los Reyes & 62 & Yanga \\
\hline 28 & Ixhuatlan de Madero & 63 & Zacualpan \\
\hline 29 & Ixhuatlan del Café & 64 & Zontecomatlan de López y Fuentes \\
\hline 30 & Jilotepec & & \\
\hline 31 & La Antigua & & \\
\hline 32 & Magdalena & & \\
\hline 33 & Mecayapan & & \\
\hline 34 & Orizaba & & \\
\hline 35 & Pajapan & & \\
\hline
\end{tabular}

